\title{
Sphenoid Sinus Polyp
}

National Cancer Institute

\section{Source}

National Cancer Institute. Sphenoid Sinus Polyp. NCI Thesaurus. Code C3933.

A polyp that arises from the sphenoid sinus mucosa. It is characterized by the presence

of edematous tissue infiltrated by inflammatory cells, including eosinophils. Causes include allergic rhinitis, chronic sinusitis, and cystic fibrosis. 